\title{
Uterine glycolytic enzyme expression is affected by knockout of different estrogen receptor subtypes
}

\author{
MIN HU ${ }^{1,2}$, YUEHUI ZHANG ${ }^{2,3}$, EMIL EGECIOGLU $^{2}$, XIN LI $^{2,4,5}$, LINUS R. SHAO ${ }^{2}$ and HÅKAN BILLIG ${ }^{2}$ \\ ${ }^{1}$ Department of Traditional Chinese Medicine, The First Affiliated Hospital of Guangzhou Medical University, \\ Guangzhou, Guangdong 510120, P.R. China; ${ }^{2}$ Department of Physiology/Endocrinology, Institute of Neuroscience \\ and Physiology, The Sahlgrenska Academy, University of Gothenburg, 40530 Gothenburg, Sweden; \\ ${ }^{3}$ Department of Obstetrics and Gynecology, Key Laboratory and Unit of Infertility in Chinese Medicine, \\ First Affiliated Hospital, Heilongjiang University of Chinese Medicine, Harbin, Heilongjiang 150040; \\ ${ }^{4}$ Department of Gynecology, Obstetrics and Gynecology Hospital of Fudan University; ${ }^{5}$ Shanghai Key Laboratory of \\ Female Reproductive Endocrine Related Diseases, Fudan University, Shanghai 200011, P.R. China
}

Received April 30, 2019; Accepted July 1, 2019

DOI: 10.3892/br.2019.1234

\begin{abstract}
The estrogen signaling pathway via nuclear estrogen receptors (ER) $\alpha$ and $\beta$ is considered to be the master regulator of the cellular glucose metabolism in the uterus. While in vivo animal studies have demonstrated that $17 \beta$-estradiol (E2) treatment increases the expression levels and activities of several glycolytic enzymes in the uterus, the specific ER subtype-dependent regulation of key glycolytic enzymes in the uterus has not been experimentally verified. In this study, the localization of ER $\alpha$ and $E R \beta$ in human and mouse endometria were evaluated using immunohistology. Given that ER $\alpha$ and $\operatorname{ER} \beta$ are not functionally equivalent, $\operatorname{ER} \alpha, \operatorname{ER} \beta$ and $\operatorname{ER} \alpha \beta$ knockout $\left(E R \alpha^{-/-}, E R \beta^{-/-}\right.$and $\left.E R \alpha \beta^{-/-}\right)$mice were utilized to determine the expression pattern of glycolytic enzymes in the uterus. It was found that the level of ER $\alpha$ was higher than that of ER $\beta$ in the human and mouse endometrial epithelial and stromal cells, and both receptors were downregulated by $\mathrm{E} 2$ treatment in the mouse uterus. The expression of the hexokinase 1 and GAPDH was increased in $\mathrm{ER}^{-/-}$and $\mathrm{ER} \beta^{-/-}$mice compared with wild-type controls. Increased phosphofructokinase expression was observed in $\mathrm{ER} \alpha^{-/}$and $\mathrm{ER} \alpha \beta^{-/-}$mice, whereas increased pyruvate kinase isozyme
\end{abstract}

Correspondence to: Dr Linus R. Shao, Department of Physiology/Endocrinology, Institute of Neuroscience and Physiology, The Sahlgrenska Academy, University of Gothenburg, Medicinaregatan 11, 40530 Gothenburg, Sweden

E-mail: linus.r.shao@fysiologi.gu.se

Abbreviations: E2, 17 $\beta$-estradiol; ER, estrogen receptor; WT, wild-type; HK, hexokinase; PFK, phosphofructokinase; PKM2, pyruvate kinase isozyme M2; PDH, pyruvate dehydrogenase; GLUT, glucose transporter; PCOS, polycystic ovary syndrome

Key words: estrogen receptor subtypes, glycolysis, uterus, knockout mice, polycystic ovary syndrome
M2 and pyruvate dehydrogenase expression was observed in $E R \beta^{-/-}$and $E R \alpha \beta^{-/-}$mice. The findings indicated for the first time that while estrogen regulates $\mathrm{ER} \alpha$ and $\mathrm{ER} \beta$ expression in the uterus, ER $\alpha$ and $\mathrm{ER} \beta$ selectively regulate uterine glycolytic enzyme expression during glycolysis. Additionally, the link between endometrial ER subtypes and glycolysis in women with polycystic ovary syndrome (PCOS) is discussed. The findings suggested that the E2-dependent ER-mediated regulation of glycolysis may be involved in the disturbance of the glucose metabolism in patients with PCOS with endometrial dysfunction.

\section{Introduction}

Estrogen elicits many different responses in female reproductive tissues, including the ovary and uterus, as well as in extra-reproductive tissues, such as the brain, adipose tissue and the liver $(1,2)$. It is well known that numerous, but not all, of the concerted actions of estrogen are mediated through binding to two nuclear estrogen receptors (ERs), ER $\alpha$ and ER $\beta$ (1), both of which belong to a family of hormone-activated transcription factors and share common structural and functional domains (3). Although there is only $\sim 60 \%$ homology in the ligand binding domain between $\operatorname{ER} \alpha$ and $\operatorname{ER} \beta$, the receptors exhibit a similar binding affinity to endogenous $17 \beta$-estradiol (E2) (3). While ER $\alpha$ and ER $\beta$ can homo- or heterodimerize in vivo, they are not functionally equivalent, and in vitro experiments show that ER $\beta$ functions as a transcriptional inhibitor of $\mathrm{ER} \alpha$ when $\mathrm{ER} \alpha$ and $\mathrm{ER} \beta$ are co-expressed (4). Although ER $\alpha$ and ER $\beta$ are often co-expressed in estrogen target cells under physiological conditions and although they can act together to regulate gene transcription $(1,5)$, the cellular localization and abundance of the two receptors show distinct patterns in human endometrial epithelial and stromal cells (5). For example, ER $\alpha$ represents the most prominent receptor type in the endometrial epithelial and stromal cells during the menstrual cycle, whereas ER $\beta$ is found predominantly in the endometrial stromal cells in the late secretory phase (5). Direct 
evidence for essential roles of the estrogen signaling pathway in uterine physiology and disease is provided by different ER knockout and mutation studies in mice $(1,3)$ and rats $(6)$. It has been reported that female $\mathrm{ER} \alpha \beta^{-/-}$and $E R \alpha^{-/-}$mice and female $\mathrm{ER} \alpha^{-/-}$rats are insensitive to $\mathrm{E} 2$ stimulation and they exhibit uterine hypoplasia and infertility, which is in contrast to loss of $\operatorname{ER} \beta\left(E R \beta^{--}\right)$in female mice that leads to subfertility. Moreover, changes in ER $\alpha$ expression levels and the $\mathrm{ER} \alpha$ : ER $\beta$ ratio are considered to be the main factors behind several gynecological disorders, including impaired fertility and endometrial hyperplasia and carcinoma $(5,7)$.

Polycystic ovary syndrome (PCOS), like numerous complex diseases, has a multifaceted etiology and pathophysiology, and it is associated with hormonal and metabolic impairments, ovarian dysfunction, menstrual irregularity and infertility $(8,9)$. Due to chronic anovulation, patients with PCOS experience sustained and persistent estrogen stimulation but minimal or completely absent progesterone stimulation $(10,11)$, and patients with PCOS with endometrial hyperplasia have a four-fold greater risk of developing endometrial carcinoma than non-PCOS controls (12). Preclinical and clinical studies have provided evidence that the endometrium from PCOS-like rodents and patients with PCOS displays morphologically normal, but structurally and biochemically abnormal responses to hormone stimulation (10,13-17). Although few PCOS endometrial samples have been analyzed, there is some controversial evidence that levels of endometrial ER $\alpha$ and ER $\beta$ mRNA and/or protein are higher in patients with PCOS compared with phase-matched non-PCOS controls, regardless of whether endometrial hyperplasia is present or not $(18,19)$. Moreover, studies have previously shown that $\operatorname{ER} \alpha$ and $\operatorname{ER} \beta$ mRNAs are increased in PCOS-like rodent uteri $(20,21)$. These preclinical and clinical findings suggest that altered expression and function of both ERs contribute to endometrial dysfunction in patients with PCOS.

Glycolysis is an energy-producing mechanism that is regulated by different levels and activities of enzymes, such as hexokinase $(\mathrm{HK})$, phosphofructokinase (PFK) and pyruvate kinase (PK) (22). E2 is a master regulator of endometrial cell proliferation (23) and has been shown to increase HK1/2 and PK isozyme M2 (PKM2) activities, as well as glycolytic flux in the rat uterus in vivo (24-26) and in human endometrial stromal cells in vitro (27). Importantly, functional experiments demonstrated that de novo synthesis of E2 in stromal cells facilitates the decidualization process in the mouse uterus, which is a prerequisite for successful implantation and establishment of pregnancy (28). It was reported that the regulation and localization of uterine $\mathrm{ER} \alpha$ but not $\mathrm{ER} \beta$ mRNA was associated with the onset of early implantation in mice (29), and the acceleration of glycolysis is required for endometrial decidualization in humans and mice $(30,31)$. Moreover, suppression of HK2 levels inhibited the proliferation and differentiation of human endometrial stromal cells in vitro (32). Taken together, these in vivo and in vitro studies suggest that it is possible that uterine E2-regulated glycolysis via ER $\alpha$ activation contributes to successful implantation and the establishment of pregnancy. However, whether uterine glycolysis is regulated by E2 in a specific ER $\alpha$ - and/or ER $\beta$-dependent manner remains unclear.

In this study, the localization and regulation of ER $\alpha$ and $\mathrm{ER} \beta$ in human and mouse endometria was assessed and
ER-specific knockout mice that lack $\mathrm{ER} \alpha$ and/or $\operatorname{ER} \beta\left(\mathrm{ER} \alpha \beta^{-/-}\right.$, $\mathrm{ER} \alpha^{-/-}$and $\mathrm{ER} \beta^{-/}$) were used to determine whether the selective contribution of ER $\alpha$ and $E R \beta$ results in the differential expression of key glycolytic enzymes in the mouse uterus.

\section{Materials and methods}

Animals and tissue collection. Two distinct experiments were performed with the animals. In the first experiment, intact prepubertal female C57BL/6J mice (Taconic Biosciences) at 26 days of age with a body weight (BW) of 13-15 g were used to avoid the complexity of ovarian functions associated with estrous cycles and endogenous surges of gonadotropins $(33,34)$. Animals ( $n=5 /$ group) were given a subcutaneous injection of $0.5 \mu \mathrm{g} \mathrm{E} 2 / \mathrm{g} \mathrm{BW}$ (in $100 \mu \mathrm{l}$ sesame oil) or vehicle (100 $\mu 1$ sesame oil; Sigma-Aldrich; Merck KGaA) alone for 4 days (35). In the second experiment, homozygous mutant female mice lacking the genes for $E R \alpha \beta, E R \alpha$ and $E R \beta$ were utilized (age, 60-65 days; weight, 20-25 g); the generation of female $E R \alpha \beta^{-/-}, E R \alpha^{-/-}$and $E R \beta^{-/-}$mice has been previously described (36-38). Scanbur AB bred and provided the different ER knockout mice; animals were inbred on a C57BL/6J background and littermate controls were used in all groups. All adult ER knockout mice were compared to isogenic wild-type (WT) age/weight-matched littermates at the same diestrus stage of the estrous cycle ( $n=4 /$ group) (39).

Under anesthesia, the uteri were removed and stripped of fat and connective tissue. One side of the uterus in each animal was fixed in $4 \%$ formaldehyde neutral-buffered solution for $24 \mathrm{~h}$ at $4^{\circ} \mathrm{C}$ and then embedded in paraffin for immunohistochemical analysis. The other side was immediately frozen in liquid nitrogen and stored at $-70^{\circ} \mathrm{C}$ for subsequent western blot analysis. All mice were housed in polycarbonate plastic cages with free access to food pellets and water at the infection-free animal facility of University of Gothenburg under a controlled temperature of $22 \pm 2^{\circ} \mathrm{C}$ at $55-65 \%$ humidity with a $12-\mathrm{h}$ light/dark cycles.

Human endometrial tissue collection. Endometrial tissues were obtained from reproductive-aged women (range, 25-45 years) during the proliferative phase of the menstrual cycle who were undergoing routine gynecological investigation. Tissues were collected in Obstetrics and Gynecology Hospital of Fudan University between March and October 2014. None of selected patients had been exposed to any hormonal or steroidal therapies within three months prior to tissue sampling. Each endometrial sample was diagnosed and staged by routine pathology analysis using standard histological criteria (40). All tissues were fixed in $10 \%$ neutral formalin solution for $24 \mathrm{~h}$ at $4^{\circ} \mathrm{C}$ and embedded in paraffin for immunohistochemical analysis.

The animal study was approved by the Animal Care and Use Committee of the local Ethics Committee of the University of Gothenburg (Sweden) and all animal experiments and care procedures were performed in compliance with the institutional guidelines for the care and use of animals in research (170-2008 and 236-2012). The human study protocol conformed to the principles outlined in the Declaration of Helsinki under approval from the institutional Ethics Review Committee of the Obstetrics and Gynecology Hospital of Fudan University 
(approval no. OGHFU 2013-23). Appropriate written informed consent was obtained from all patients.

Total protein extraction and western blot analysis. Protein lysates were prepared from mouse uterine tissues using ice-cold RIPA buffer (Sigma-Aldrich; Merck KGaA) supplemented with cOmplete Mini protease inhibitor cocktail tablets (Roche Diagnostics) and PhosSTOP phosphatase inhibitor cocktail tablets (Roche Diagnostics). Protein concentration determination and a western blot analysis protocol were previously described $(13,41,42)$. After determining the total protein concentration by Bradford protein assay (Thermo Fisher Scientific, Inc.), 30- $\mu$ g protein was resolved on $4-12 \%$ Bis-Tris gradient gels (Novex; Thermo Fisher Scientific, Inc.) and transferred to PVDF membranes. The membranes were blocked with $0.01 \mathrm{M}$ Tris-buffered saline supplemented with $0.1 \%$ (v/v) Triton X-100 (TBST) containing 5\% non-fat dry milk for $1 \mathrm{~h}$ at room temperature (RT) and then probed with different primary antibodies in the blocking buffer overnight at $4^{\circ} \mathrm{C}$. The primary antibody details are as follows: HK1 (1:100; cat. no. 2024), HK2 (1:100; cat. no. 2867), PFK (1:100; cat. no. 8164), GAPDH (1:200; cat. no. 5174), PKM2 (1:100; cat. no. 4053), pyruvate dehydrogenase (PDH; 1:100; cat. no. 3205) (all from Cell Signaling Technology, Inc.,) ER $\alpha$ (1:300; cat. no. 6F11; Novocastra Laboratories Ltd.; Leica Biosystems), ER $\beta$ (1:1,000; cat. no. 06-629; Upstate Biotechnology, Inc.), progesterone receptor (PR; 1:100; cat.no. sc-538), proliferating cell nuclear antigen (PCNA; 1:100; cat. no. sc-25280) (both from Santa Cruz Biotechnologies, Inc.), total caspase-3 (1:500; cat. no. C92-605; BD Biosciences) and $\beta$-actin (1:500; cat. no. A1978; Sigma-Aldrich; Merck KGaA). On day 2, the membranes were washed with TBST followed by either anti-rabbit IgG horseradish peroxidase (HRP)-conjugated goat (1:1,000; cat. no. A0545) or anti-mouse IgG HRP-conjugated goat (1:1,000; cat. no. A2304) secondary antibody (both from Sigma-Aldrich; Merck KGaA) for $1 \mathrm{~h}$ at RT. Chemiluminescence signals were detected using SuperSignal West Dura substrate following the manufacturer's instructions (Thermo Fisher Scientific, Inc.). Band densitometry and quantification was performed using Image Laboratory (v5.0; Bio-Rad Laboratories, Inc.) and the protein band densities were normalized to $\beta$-actin. To reprobe the membrane with another antibody, the blot was washed with TBST 3x for $10 \mathrm{~min}$ at RT and incubated with stripping buffer (65 mM Tris-HCl, $2 \%$ SDS and $100 \mathrm{mM} \beta$-mercaptoethanol, $\mathrm{pH} \mathrm{6.8)} \mathrm{at} \mathrm{RT} \mathrm{for} 15 \mathrm{~min}$. Then the steps regarding the washing, blocking and probing of the membrane were repeated.

Immunohistochemical analyses and microscopy. Immunohistochemistry and dual-immunofluorescence were performed according to previously described methods $(20,42,43)$. Human endometria and mouse uterine and ovarian tissues were fixed in $4 \%$ formaldehyde neutral-buffered solution for $24 \mathrm{~h}$ at $4^{\circ} \mathrm{C}$, paraffin-embedded and $5 \mu \mathrm{m}$ sections were obtained. Two sections per sample were stained using standard hematoxylin and eosin methods (13). After deparaffinization (xylene, $10 \mathrm{~min}$ at RT) and rehydration (100, 90 and $70 \%$ ethanol, each $10 \mathrm{~min}$ at RT), the sections were immersed in epitope retrieval buffer $(10 \mathrm{mM}$ sodium citrate buffer, $\mathrm{pH}$ 6.0) and heated in a $700 \mathrm{~W}$ microwave for $15 \mathrm{~min}$. Sections were subsequently rinsed twice with deionized $\mathrm{H}_{2} \mathrm{O}$ and once with TBST, each $5 \mathrm{~min}$ at RT. Endogenous peroxidase was removed and non-specific binding was blocked by incubation with $3 \% \mathrm{H}_{2} \mathrm{O}_{2}$ for $10 \mathrm{~min}$ at RT and then with $10 \%$ normal goat serum for $1 \mathrm{~h}$ at RT. After incubation with primary antibody overnight at $4^{\circ} \mathrm{C}$ in a humidified chamber, same sections were incubated with secondary antibodies (30 min; RT) and stain from the avidin-biotinylated-peroxidase $\mathrm{ABC}$ kit according to the manufacturer's instructions (Vector Laboratories, Inc.; Maravai LifeSciences) followed by a 5-min treatment with 3,3'-diaminobenzidine (SK-4100; Vector Laboratories, Inc.; Maravai LifeSciences) at RT. All sections were incubated with DAB for the same length of time so that comparisons could be made between individual samples and all slides were stained in a single run to eliminate inter-experiment variations in staining intensity. Digital images of stained sections were obtained with a Nikon E-1000 microscope (Nikon Corporation) using bright-field optics (magnification, x2, x10 and x40) and photomicrographed using Easy Image 1 (Bergström Instrument AB). Primary antibodies for immunohistochemistry included: $\mathrm{ER} \alpha$ (1:50; cat. no. MC-20; Santa Cruz Biotechnologies Inc.), ER $\beta$ (1:300; cat. no. 06-629; Upstate Biotechnology, Inc.), ER $\beta 1$ (1:100; cat. no. PPG5/10), ERß2 (1:100; cat. no. 57/3) (both from AbD Serotec; Bio-Rad Laboratories, Inc.), cytokeratin 8 (1:200; cat. no. C5301; Sigma-Aldrich; Merck KGaA) and Ki-67 (1:100; cat. no. 9027; Cell Signaling Technology, Inc.).

Human and mouse endometrial tissue sections were blocked in PBS containing 1\% BSA and 3\% fat-free milk for $1 \mathrm{~h}$ at room temperature. Sections were incubated with the anti-ER $\alpha$ (1:50; cat. no. MC-20; Santa Cruz Biotechnologies for human tissues; and 1:100; cat. no. 6F11; Novocastra Laboratories for mouse tissues), anti-ER $\beta 1$ (1:100; cat. no. PPG5/10; AbD Serotec for human tissues), anti-ER $\beta 2$ (1:100; cat. no. 57/3; AbD Serotec for human tissues) or anti-ER $\beta$ (1:300; cat. no. 06-629; Upstate Biotechnology for mouse tissues) antibody in PBS supplemented with $0.1 \%$ (v/v) Triton X-100 (PBST) containing 1\% BSA and $3 \%$ fat-free milk overnight at $4{ }^{\circ} \mathrm{C}$. After washing with PBST three times for $5 \mathrm{~min}$ each, sections were incubated with Alexa Fluor 594-conjugated goat polyclonal anti-rabbit IgG (1:250; cat. no. A11037), Alexa Fluor 488-conjugated goat polyclonal anti-rabbit IgG (1:250; cat. no. A11008) or Alexa Fluor 488-conjugated goat polyclonal anti-mouse IgG (1:250; cat. no. A11039) (all from Invitrogen; Thermo Fisher Scientific, Inc.) for $1 \mathrm{~h}$ at RT. After the sections were washed with PBST, they were examined under an Axiovert 200 confocal microscope (magnification, x20 and x60; Zeiss $\mathrm{GmbH}$ ) equipped with a laser-scanning confocal imaging LSM 510 META system (Carl Zeiss AG) and were photomicrographed. Background settings were adjusted from the examination of negative control specimen; different controls for non-specific staining have been described previously (43).

Statistical analysis. For all experiments, $\mathrm{n}$ represents the numbers of individual animals. Data are presented as the mean \pm SEM ( $n=4 /$ group). Statistical analyses were performed using the SPSS version 24.0 (IMB Corp.). The normal distribution of the data was tested by Shapiro-Wilk test. Differences between groups were analyzed by one-way ANOVA followed by Bonferroni's post hoc test for normally distributed data 
A
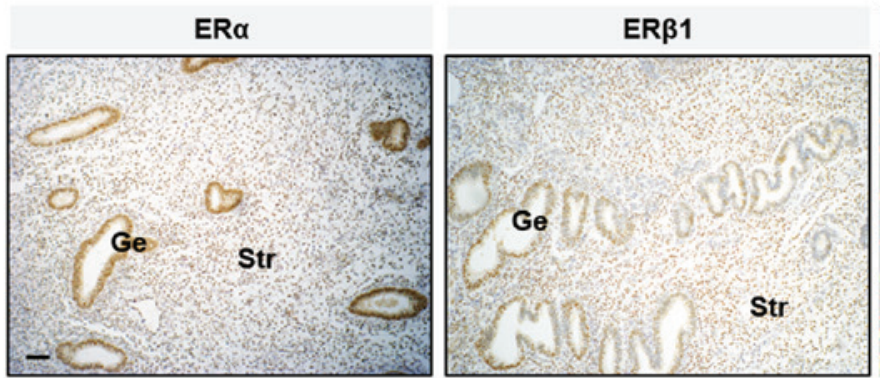

ER $\alpha / E R \beta 1 / E R \alpha-E R \beta 1$
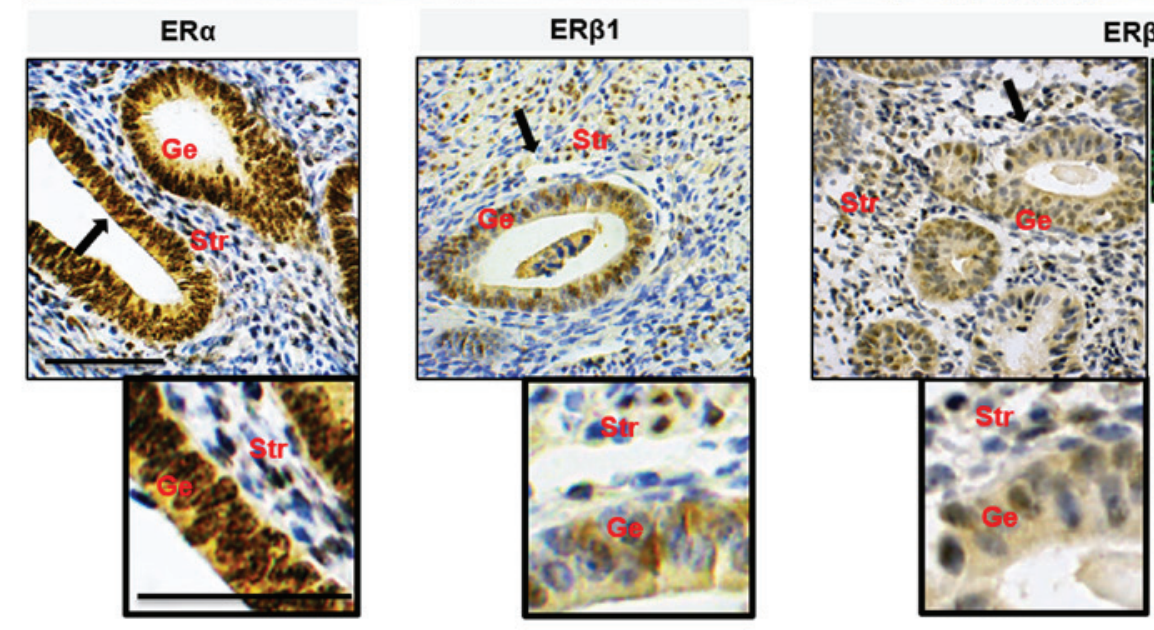

B
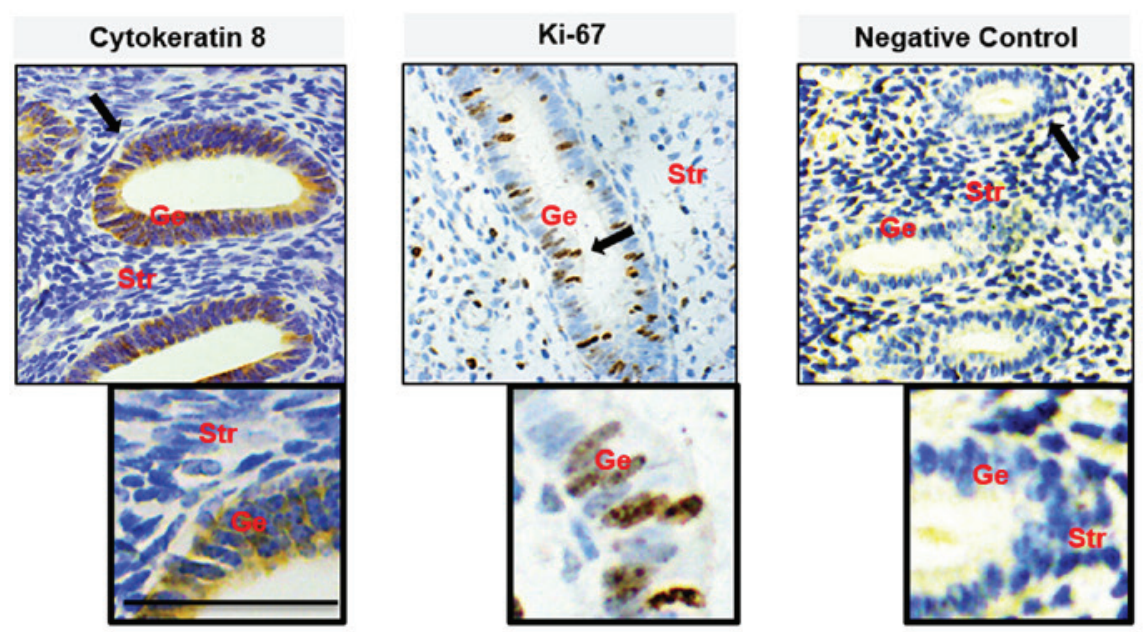

Figure 1. Localization of ER subtypes in the human endometria. (A) The localization of ER $\alpha$ (red) and ER $\beta$ (green). (B) Cellular marker proteins of cytokeratin 8 and $\mathrm{Ki} 67$ in human endometria during the estrogen-dominant proliferative phase was assessed using immunohistology. Sections exposed to human endometrial tissues (the proliferative phase) were used as negative controls. Brown spots were observed using 3,3'-diaminobenzidine as the chromogen. Black arrows indicate areas shown at higher magnification; scale bar, $100 \mu \mathrm{m}$. Ge, glandular epithelial cells; Str, stromal cells; ER, estrogen receptor.

or by the Kruskal-Wallis test followed by Mann-Whitney $\mathrm{U}$ test for skewed data. $\mathrm{P}<0.05$ was considered to indicate a statistically significant difference.

\section{Results and Discussion}

The endometrium is composed of a lining of surface epithelium and associated glands, and a stroma composed of connective tissue (5). During each reproductive cycle, the endometrial epithelial and stromal cells display distinct and well-defined patterns of functional differentiation under the cyclic influence of estrogen and progesterone (23). Increasing evidence suggests that the differential effects of estrogen on endometrial cells likely depend on the total amount of cellular ERs and/or the ratio of $E R \alpha$ to $E R \beta(5,7)$. In this study, it was found that the level of ER $\alpha$ was higher than ER $\beta$ in human (Fig. 1) and mouse (Fig. 2A and B) endometrial epithelial and stromal cells. This suggested that ER $\alpha$ was the predominant ER expressed in the uterus. Immunohistochemical analysis of tissues from women during the estrogen-dominant proliferative phase showed strong positive nuclear staining for ER $\alpha$ in epithelial and stromal cells but weak to moderate positive nuclear staining for ER $\beta 1$ and $E R \beta 2$, and $E R \alpha$ immunoreactivity was more abundant in the nucleus than in the cytoplasm in epithelial cells. ER $\alpha$ and ER $\beta 1$ were heterogeneously co-localized in the nucleus of epithelial and stromal cells. Compared with 
A

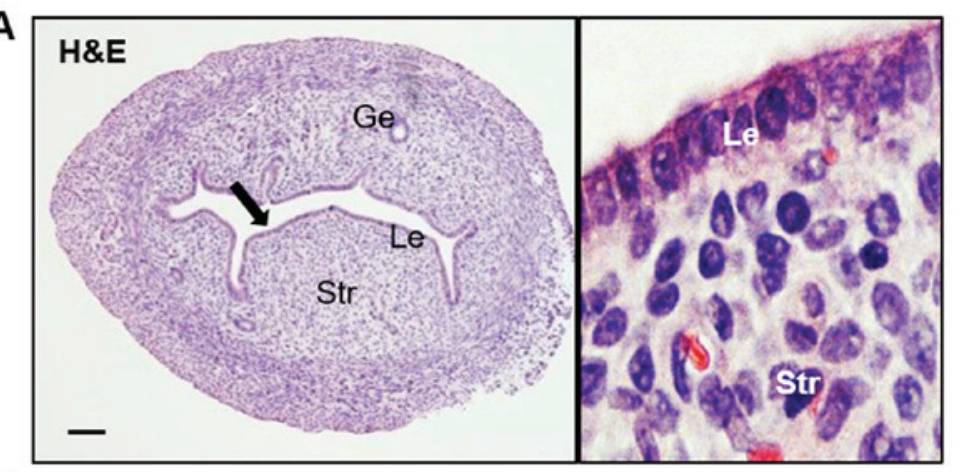

B

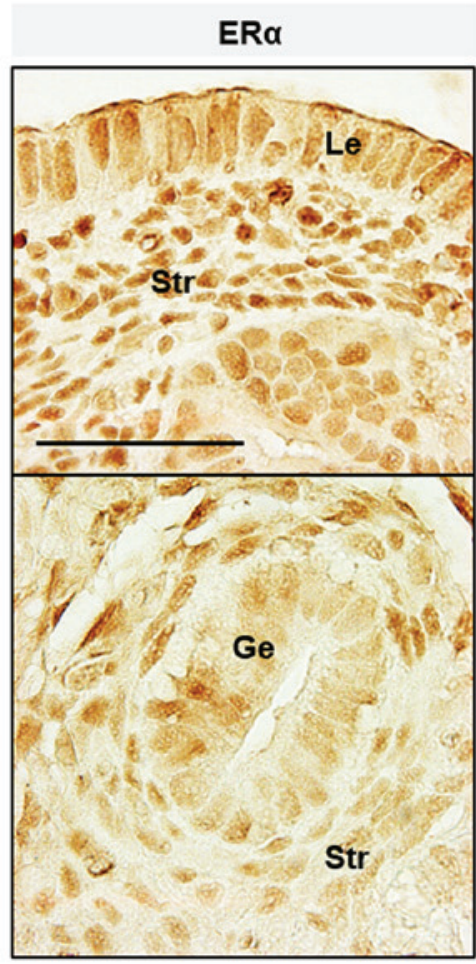

\section{ERa}

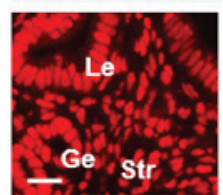

ER $\beta$

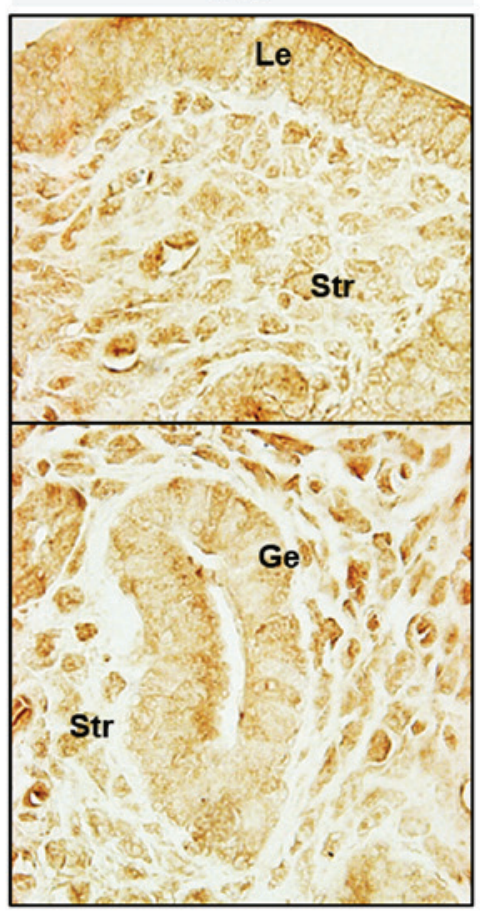

ER $\beta$

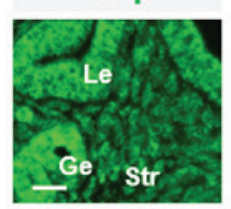

C

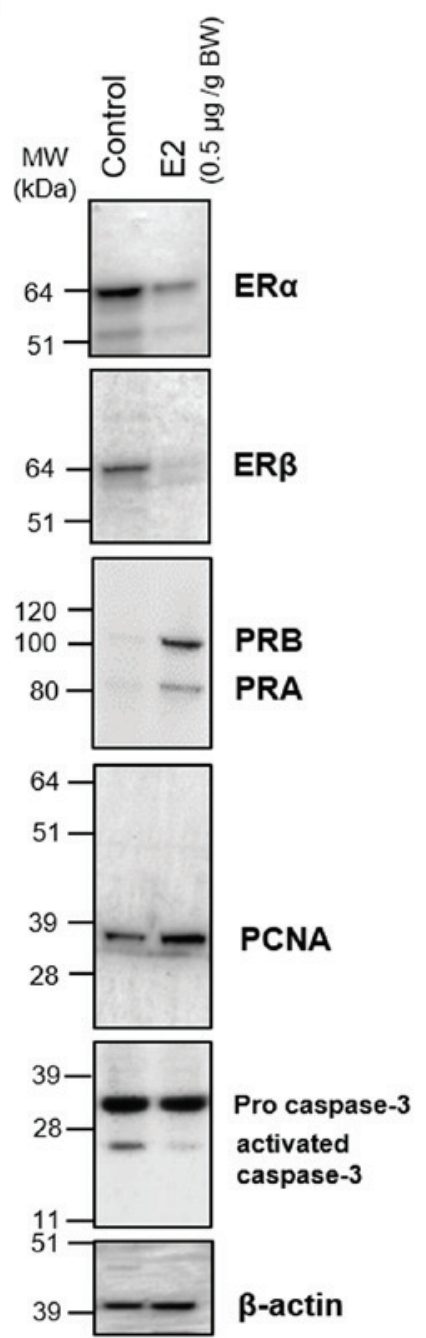

Figure 2. Localization of ER subtypes in the mouse uterus. (A) Uterine tissue sections stained with hematoxylin and eosin staining. (B) Immunohistological localization of ER $\alpha$ and ER $\beta$ in the mouse uterus. A mouse ovarian tissue section was used as the positive control for the anti-ER $\beta$ antibody specificity. Immunohistochemistry was performed using 3,3'-diaminobenzidine (brown). Immunofluorescence detection shows ER $\alpha$ (red) and ER $\beta$ (green). Black arrows indicate areas shown at higher magnification; scale bar, $100 \mu \mathrm{m}$. (C) Western blot analysis of ER subtypes, proliferation and apoptosis markers in the prepubescent mouse uterus. E2, 17ß-estradiol; BW, body weight; MW, molecular weight; Le, luminal epithelial cells; Ge, glandular epithelial cells; Str, stromal cells; GC, granulosa cells; TC, thecal cells; ER, estrogen receptor; PR, progesterone receptor; proliferating cell nuclear antigen.

ER $\beta 1$, the ER $\beta 2$ immunoreactivity was evenly detected in the nuclei and cytoplasm of epithelial and stromal cells (Fig. 1A). These observations of endometrial cellular ER $\alpha$ and ER $\beta$ localization were broadly in agreement with previous human studies (5). As shown in Fig. 2B, ER $\alpha$ immunoreactivity was detected in the nuclei of epithelial and stromal cells, whereas ER $\beta$ immunoreactivity was detected mainly in the nuclei of stromal cells only. It was found that prepubescent mice treated chronically with E2 had decreased ER $\alpha$ and ER $\beta$ protein expression and increased PR isoform protein expression compared with the vehicle-treated controls (Fig. 2C). In the same experimental mouse uterus, increased PCNA, a cellular marker for proliferation, was associated with decreased activated caspase-3, a marker for cell apoptosis (Fig. 2C). These finding confirmed that E2 contributed to normal endometrial growth through the direct regulation of uterine $\mathrm{ER} \alpha$ and $\mathrm{ER} \beta$ in vivo.

There is increasing clinical and experimental evidence suggesting that aberrant regulation of ER $\alpha$ and ER $\beta$ expression is involved in the development and progression of several reproductive and metabolic diseases $(1,2)$. For example, one female patient with a homozygous ER $\alpha$ mutation and female 

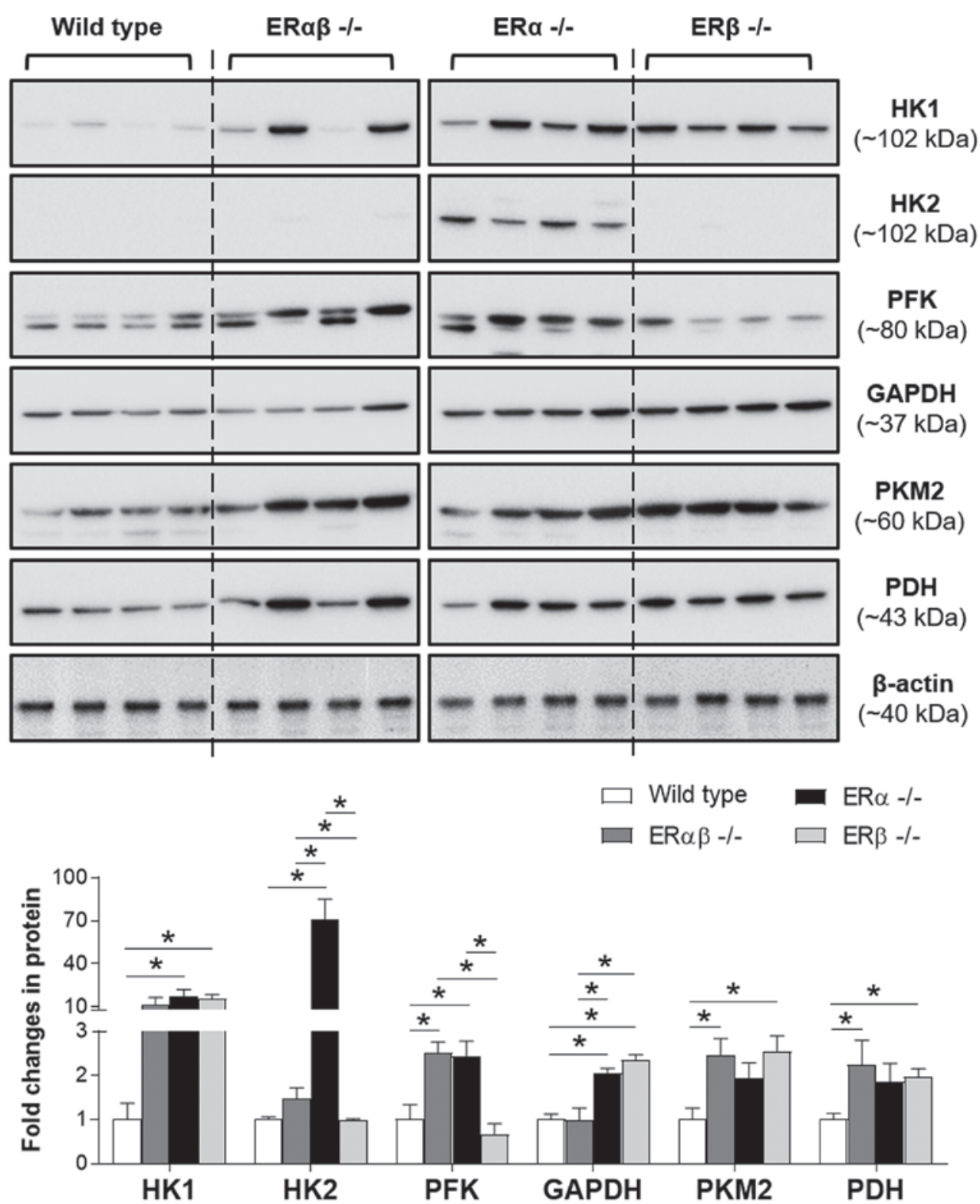

Figure 3. Expression of glycolytic enzymes in ER knockout mouse uteri. Protein levels of glycolytic enzymes were determined by western blot and are presented relative to $\beta$-actin ( $n=4$ /group). Data are expressed as the mean \pm SEM. ${ }^{*} \mathrm{P}<0.05$. HK, hexokinase; PFK, phosphofructokinase; PKM2, pyruvate kinase isoform M2; $\mathrm{PDH}$, pyruvate dehydrogenase.

mice and rats lacking ER $\alpha$ display similar polycystic ovary phenotypes and infertility $(6,44,45)$ as observed in patients with PCOS. Moreover, an ER $\beta$ polymorphism (+1730 G/A) has been implicated in susceptibility to the development of PCOS in humans (46). While the exact mechanisms of the pathogenesis of PCOS remains unknown, increasing evidence suggests that PCOS is a clinically heterogeneous and multifactorial disorder $(8,9)$. Taken together, these findings indicate that multiple cellular and molecular signaling pathways are likely to be involved in its pathogenesis.

Glycolysis is the splitting apart of a glucose molecule in the cytosol by a sequence of enzymatic reactions, and its efficient operation requires adequate glucose uptake mediated by a number of glucose transporters (GLUTs) (47). Among the GLUTs, GLUT1 has been identified as the most prominent in endometrial tissues in vivo (48). Thus, it is thought that GLUT1 is responsible for the basal level of glucose uptake needed for normal glucose utilization in the uterus. It has been reported that E2 decreases glucose uptake in association with decreased GLUT1 expression in human and mouse endometrial stromal cells in vitro (49). Although there is no cyclical fluctuation of insulin-sensitive GLUT4 expression observed in human endometrium (50), it was previously shown that GLUT4 mRNA and protein expression are decreased in patients with PCOS compared with non-PCOS controls (50-52) and a similar observation has been made in the PCOS-like rat uterus $(13,51)$. An analysis of gene expression in endometrial tissues found significantly reduced levels of key glycolytic genes in patients with PCOS compared with non-PCOS controls (53). Reproductive dysfunction and infertility are common in patients with PCOS $(11,54)$, who often display E2-mediated endometrial hyperproliferation (55). Further studies have demonstrated that several proteins involved in cytosolic glycolysis, such as PKM2, are impaired 


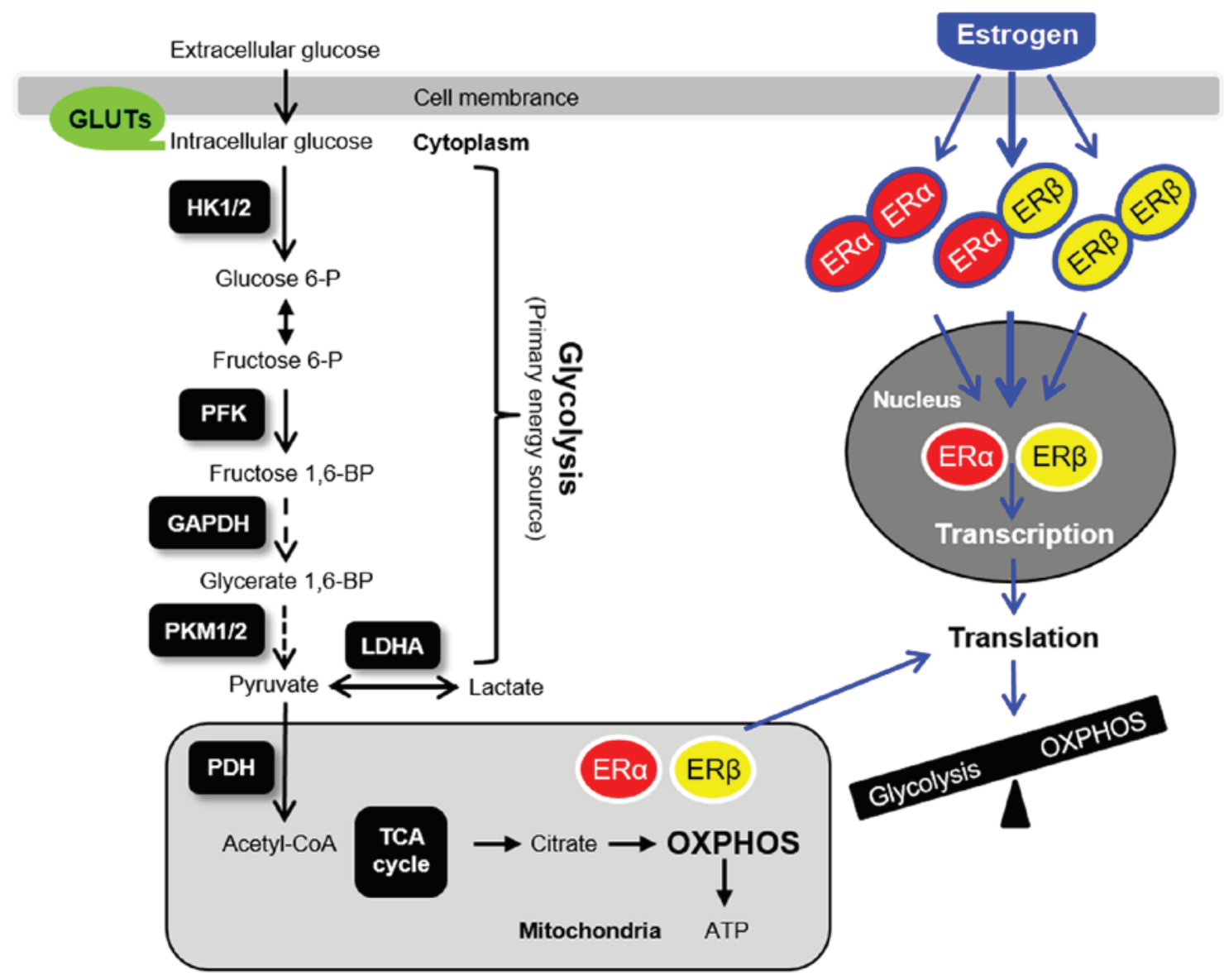

Figure 4. Glycolysis, mitochondria-mediated energy metabolism and ER-mediated genomic actions in the uterus. GLUT, glucose transporter; HK, hexokinase; PFK, phosphofructokinase; PKM, pyruvate kinase isoform; LDHA, lactate dehydrogenase A; PDH, pyruvate dehydrogenase; OXPHOS, oxidative phosphorylation; TCA, tricarboxylic acid; ER, estrogen receptor; P, phosphate; BP, bisphosphate.

in the endometrium of patients with PCOS and in PCOS-like animals with an endometrial hypoplasia phenotype $(13,56)$. These findings support the notion that dysregulation of E2-mediated glycolysis is, at least partially, involved in the endometrial dysfunction in patients with PCOS with endometrial hyperplasia.

Changes in the glucose metabolism are a fundamental part of many biological processes (22). However, at present there is limited knowledge as to whether the estrogenic regulation of the uterine glucose metabolism depends on different ER subtypes. In this study, the expression pattern of uterine glycolytic enzymes in ER $\alpha \beta^{-/}, E R \alpha^{-/-}$and $E R \beta^{-/-}$mice was compared with WT controls (Fig. 3). Using western blot analysis, it was found that HK1 and GAPDH expression was significantly increased in $\mathrm{ER}^{-/-}$and $\mathrm{ER} \beta^{-/-}$mice compared with the WT controls. Moreover, significantly increased HK2 and PFK expression was observed in $\mathrm{ER}^{-/-}$mice compared with the WT controls, whereas significantly increased PKM2 and $\mathrm{PDH}$ expression was observed for $\mathrm{ER} \beta^{-/-}$mice compared with the WT controls. As indicated in the expression pattern of glycolytic enzymes, disruption of $\operatorname{ER} \alpha$ and $\operatorname{ER} \beta\left(\operatorname{ER} \alpha \beta^{--}\right)$ resulted in significantly increased PFK, PKM2 and PDH expression compared with the WT controls. This suggested that although ER $\alpha$ is the predominant ER expressed in the uterus, ER $\beta$ may partially compensate for the loss of ER $\alpha$ by increasing the expression of certain glycolytic enzymes in the uterus. Furthermore, the significantly increased uterine $\mathrm{PDH}$ expression in ER $\beta^{-/-}$but not $\mathrm{ER} \alpha^{-/-}$animals compared with the WT controls suggested that the cell's mitochondria contained primarily $\mathrm{ER} \beta$ and not $\mathrm{ER} \alpha$ (5). It is noteworthy that the estrogen responsiveness becomes more complex because human and rodent reproductive tissues contain splice variants of ER $\alpha$ and $\operatorname{ER} \beta(5,35,57)$, and the two subtypes form heterodimers with in vivo (3). It was previously shown that $\mathrm{ER}^{-/-}$mouse uteri, similar to $\mathrm{ER} \alpha \beta^{-/-}$mouse uteri, remain to have one ER $\alpha$ splice form (35) and the levels of estrogen-regulated ER $\alpha$ protein are positively associated with endometrial hyperplasia in patients with PCOS (56). To better understand the role of estrogen-regulated glycolysis in the endometria of patients with PCOS, further studies are needed to determine whether ER $\alpha$ splice variants are differentially regulated by E2 using well-controlled endometrial tissue samples collected from patients with PCOS with various phenotypes.

Furthermore, the western blot analysis demonstrated that two distinct forms of PFK were present in the mouse uterus (Fig. 3). PFK is synthesized as an unstable inactive monomer, which associates rapidly to form minimally active dimers essential for maintaining the tertiary structure of the enzyme (58). Several studies have shown that PFK has three isoforms (M, P and L) and differentially expresses in various mammalian tissues in vivo $(59,60)$. It is hypothesized that the PFK antibody used in this study was able to detect 
two different isoforms of PFK; however, which PFK isoform is expressed in the mouse uterus remains to be determined. As the varying ratio of PFK isoforms may determine the glycolytic rate in a tissue-specific manner (61), further work is needed to determine which PFK isoforms contribute to the uterine glycolytic rates in mice.

The role of aberrant glucose metabolism in the development of hormone-related diseases has become a topic of great interest. In addition to hyperandrogenism, numerous patients with PCOS also exhibit core metabolic manifestations, including peripheral insulin resistance $(8,9)$. Of interest, female $E R \alpha^{-/}$but not $E R \beta^{-/-}$mice develop obesity and insulin resistance (2). Hulchiy et al (62) have reported that endometrial ER $\alpha$ but not ER $\beta$ mRNA is decreased in overweight/obese patients with PCOS compared with controls, which is in contrast to the increased endometrial ER $\alpha$ and ER $\beta$ mRNA and/or protein expression observed in patients with hyperandrogenic PCOS $(18,19)$. Thus, it remains unclear how insulin resistance and hyperandrogenism differentially affect ER subtype-mediated regulation of glycolysis in the endometrium in patients with PCOS. Based on a growing number of preclinical and clinical studies $(13,18,41,42,63,64)$, it is hypothesized that abnormal steroid hormone responsiveness, such as hyperandrogenism, metabolic dysfunction, such as insulin resistance, molecular aberrations in the endometrium, such as glycolysis (Fig. 4), oxidative stress, immune factors and inflammatory uterine environments are all potential to be involved in the endometrial dysfunction observed in patients with PCOS (42). Further investigations are required to elucidate the crosstalk between these possible mechanisms in the uterus under both physiological and pathological conditions.

\section{Acknowledgements}

Not applicable.

\section{Funding}

This study was funded by grants from the Swedish Medical Research Council (grant no. 10380), the Swedish state under the ALF agreement between the Swedish government and the county councils (grant no. ALFGBG-147791), the Jane and Dan Olsson's Foundation, the Knut and Alice Wallenbergs Foundation, and the Adlerbert Research Foundation to HB and LRS, as well as the Guangzhou Medical University High-level University Construction Talents Fund (grant no. B185006010046) and the National Natural Science Foundation of China (grant no. 81774136).

\section{Availability of data and materials}

The datasets used and/or analyzed during the current study are available from the corresponding author on reasonable request.

\section{Authors' contributions}

LRS conceptualized the experiments, supervised the study and provided key research direction. $\mathrm{MH}, \mathrm{YZ}, \mathrm{EE}, \mathrm{XL}$ and LRS performed the experiments. MH and LRS took responsibility for the integrity of the data analysis. LRS wrote and revised the manuscript. HB interpreted data and provided the critical comments on the manuscript. LRS and HB provided scientific oversight and guidance. All authors read and approved the final version of the manuscript.

\section{Ethics approval and consent to participate}

The animal study was approved by the Animal Care and Use Committee of the local Ethics Committee of the University of Gothenburg (Sweden) and all animal experiments and care procedures were performed in compliance with the institutional guidelines for the care and use of animals in research (170-2008 and 236-2012). The human study protocol conformed to the principles outlined in the Declaration of Helsinki under approval from the institutional Ethics Review Committee of the Obstetrics and Gynecology Hospital of Fudan University (approval no. OGHFU 2013-23). Appropriate written informed consent was obtained from all patients.

\section{Patient consent for publication}

Not applicable.

\section{Competing interests}

The authors declare that they have no competing interests.

\section{References}

1. Hamilton KJ, Hewitt SC, Arao Y and Korach KS: Estrogen hormone biology. Curr Top Dev Biol 125: 109-146, 2017.

2. Barros RP and Gustafsson JÅ: Estrogen receptors and the metabolic network. Cell Metab 14: 289-299, 2011.

3. Hewitt SC, Winuthayanon W and Korach KS: What's new in estrogen receptor action in the female reproductive tract. J Mol Endocrinol 56: R55-R71, 2016.

4. Matthews J, Wihlén B, Tujague M, Wan J, Strom A and Gustafsson JA: Estrogen receptor (ER) beta modulates ERalpha-mediated transcriptional activation by altering the recruitment of c-Fos and c-Jun to estrogen-responsive promoters. Mol Endocrinol 20: 534-543, 2006.

5. Hapangama DK, Kamal AM and Bulmer JN: Estrogen receptor $\beta$ : The guardian of the endometrium. Hum Reprod Update 21: 174-193, 2015.

6. Rumi MA,Dhakal P,Kubota K, Chakraborty D,Lei T,Larson MA, Wolfe MW, Roby KF, Vivian JL and Soares MJ: Generation of Esrl-knockout rats using zinc finger nuclease-mediated genome editing. Endocrinology 155: 1991-1999, 2014.

7. Rodriguez AC, Blanchard Z, Maurer KA and Gertz J: Estrogen signaling in endometrial cancer: A key oncogenic pathway with several open questions. Horm Cancer 10: 51-63, 2019.

8. Azziz R, Carmina E, Chen Z, Dunaif A, Laven JS, Legro RS, Lizneva D, Natterson-Horowtiz B, Teede HJ and Yildiz BO: Polycystic ovary syndrome. Nat Rev Dis Primers 2: 16057, 2016.

9. Goodarzi MO, Dumesic DA, Chazenbalk G and Azziz R: Polycystic ovary syndrome: Etiology, pathogenesis and diagnosis. Nat Rev Endocrinol 7: 219-231, 2011.

10. Li X, Feng Y, Lin JF, Billig H and Shao R: Endometrial progesterone resistance and PCOS. J Biomed Sci 21: 2, 2014.

11. Li X and Shao R: PCOS and obesity: Insulin resistance might be a common etiology for the development of type I endometrial carcinoma. Am J Cancer Res 4: 73-79, 2014.

12. Fearnley EJ, Marquart L, Spurdle AB, Weinstein P and Webb PM; Australian Ovarian Cancer Study Group and Australian National Endometrial Cancer Study Group: Polycystic ovary syndrome increases the risk of endometrial cancer in women aged less than 50 years: An Australian case-control study. Cancer Causes Control 21: 2303-2308, 2010. 
13. Zhang Y, Sun X, Sun X, Meng F, Hu M, Li X, Li W, Wu XK, Brännström M, Shao R and Billig H: Molecular characterization of insulin resistance and glycolytic metabolism in the rat uterus. Sci Rep 6: 30679, 2016.

14. Kuyucu Y, Çelik LS, Kendirlinan Ö, Tap Ö and Mete UÖ: Investigation of the uterine structural changes in the experimental model with polycystic ovary syndrome and effects of vitamin D treatment: An ultrastructural and immunohistochemical study. Rep Biol 18: 53-59, 2018.

15. Brosens I and Benagiano G: Menstrual preconditioning for the prevention of major obstetrical syndromes in polycystic ovary syndrome. Am J Obstet Gynecol 213: 488-493, 2015.

16. Leonhardt H, Gull B, Kishimoto K, Kataoka M, Nilsson L, Janson PO, Stener-Victorin E and Hellström M: Uterine morphology and peristalsis in women with polycystic ovary syndrome. Acta Radiol 53: 1195-1201, 2012.

17. Villavicencio A, Bacallao K, Gabler F, Fuentes A, Albornoz J, Casals A and Vega M: Deregulation of tissue homeostasis in endometria from patients with polycystic ovarian syndrome with and without endometrial hyperplasia. Gynecol Oncol 104 290-295, 2007.

18. Piltonen TT: Polycystic ovary syndrome: Endometrial markers Best Pract Res Clin Obstet Gynaecol 37: 66-79, 2016.

19. Baracat MC, Serafini PC, Simões Rdos S, Maciel GA, Soares JM $\mathrm{Jr}$ and Baracat EC: Systematic review of cell adhesion molecules and estrogen receptor expression in the endometrium of patients with polycystic ovary syndrome. Int J Gynaecol Obstet 129: 1-4, 2015.

20. Hu M, Zhang Y, Feng J, Xu X, Zhang J, Zhao W, Guo X, Li J, Vestin E, Cui $\mathrm{P}$, et al: Uterine progesterone signaling is a target for metformin therapy in PCOS-like rats. J Endocrinol 237: 123-137, 2018

21. Li SY, Song Z, Song MJ, Qin JW, Zhao ML and Yang ZM: Impaired receptivity and decidualization in DHEA-induced PCOS mice. Sci Rep 6: 38134, 2016.

22. Burns JS and Manda G: Metabolic pathways of the warburg effect in health and disease: Perspectives of choice, Chain or chance. Int J Mol Sci 18: pii E2755, 2017.

23. Gellersen B and Brosens JJ: Cyclic decidualization of the human endometrium in reproductive health and failure. Endocr Rev 35: 851-905, 2014.

24. Baquer NZ and McLean P: The effect of oestradiol on the profile of constant and specific proportion groups of enzymes in rat uterus. Biochem Biophys Res Commun 48: 729-734, 1972.

25. Baquer NZ, Sochor M, Kunjara S and McLean P: Effect of oestradiol on the carbohydrate metabolism of immature rat uterus: The role of fructose-2, 6-bis-phosphate and of phosphoribosyl pyrophosphate. Biochem Mol Biol Int 31: 509-519, 1993.

26. Reiss NA: Ontogeny and estrogen responsiveness of creatine kinase and glycolytic enzymes in brain and uterus of rat Neurosci Lett 84: 197-202, 1988.

27. Singhal RL and Valadares JR: Estrogenic regulation of uterine pyruvate kinase. Am J Physiol 218: 321-327, 1970.

28. Das A, Mantena SR, Kannan A, Evans DB, Bagchi MK and Bagchi IC: De novo synthesis of estrogen in pregnant uterus is critical for stromal decidualization and angiogenesis. Proc Natl Acad Sci USA 106: 12542-12547, 2009.

29. Tan J, Paria BC, Dey SK and Das SK: Differential uterine expression of estrogen and progesterone receptors correlates with uterine preparation for implantation and decidualization in the mouse. Endocrinology 140: 5310-5321, 1999.

30. Zuo RJ, Gu XW, Qi QR, Wang TS, Zhao XY, Liu JL and Yang ZM: Warburg-like glycolysis and lactate shuttle in mouse decidua during early pregnancy. J Biol Chem 290: 21280-21291, 2015.

31. Kommagani R, Szwarc MM, Kovanci E, Gibbons WE, Putluri N, Maity S, Creighton CJ, Sreekumar A, DeMayo FJ, Lydon JP and O'Malley BW: Acceleration of the glycolytic flux by steroid receptor coactivator-2 is essential for endometrial decidualization. PLoS Genet 9: e1003900, 2013.

32. Lv H, Tong J, Yang J, Lv S, Li WP, Zhang C and Chen ZJ: Dysregulated pseudogene HK2P1 may contribute to preeclampsia as a competing endogenous RNA for hexokinase 2 by impairing decidualization. Hypertension 71: 648-658, 2018.

33. Shao R, Markström E, Friberg PA, Johansson M and Billig H: Expression of progesterone receptor (PR) A and B isoforms in mouse granulosa cells: Stage-dependent PR-mediated regulation of apoptosis and cell proliferation. Biol Reprod 68: 914-921, 2003
34. Shao R, Zhang FP, Rung E, Palvimo JJ, Huhtaniemi I and Billig H: Inhibition of small ubiquitin-related modifier-1 expression by luteinizing hormone receptor stimulation is linked to induction of progesterone receptor during ovulation in mouse granulosa cells. Endocrinology 145: 384-392, 2004.

35. Shao R, Egecioglu E, Weijdegård B, Kopchick JJ, Fernandez-Rodriguez J, Andersson N and Billig H: Dynamic regulation of estrogen receptor-alpha isoform expression in the mouse fallopian tube: Mechanistic insight into estrogen-dependent production and secretion of insulin-like growth factors. Am J Physiol Endocrinol Metab 293: E1430-E1442, 2007.

36. Couse JF, Hewitt SC, Bunch DO, Sar M, Walker VR, Davis BJ and Korach KS: Postnatal sex reversal of the ovaries in mice lacking estrogen receptors alpha and beta. Science 286: 2328-2331, 1999.

37. Lubahn DB, Moyer JS, Golding TS, Couse JF, Korach KS and Smithies O: Alteration of reproductive function but not prenatal sexual development after insertional disruption of the mouse estrogen receptor gene. Proc Natl Acad Sci USA 90: 11162-11166, 1993.

38. Krege JH, Hodgin JB, Couse JF, Enmark E, Warner M, Mahler JF, Sar M, Korach KS, Gustafsson JA and Smithies O: Generation and reproductive phenotypes of mice lacking estrogen receptor beta. Proc Natl Acad Sci USA 95: 15677-15682, 1998.

39. Feng Y, Johansson J, Shao R, Mannerås L, Fernandez-Rodriguez J, Billig H and Stener-Victorin E: Hypothalamic neuroendocrine functions in rats with dihydrotestosterone-induced polycystic ovary syndrome: Effects of low-frequency electro-acupuncture. PLoS One 4: e6638, 2009.

40. Noyes RW, Hertig AT and Rock J: Dating the endometrial biopsy. Am J Obstet Gynecol 122: 262-263, 1975.

41. Zhang Y, Hu M, Meng F, Sun X, Xu H, Zhang J, Cui P, Morina N, Li X, Li W, et al: Metformin ameliorates uterine defects in a rat model of polycystic ovary syndrome. EBioMedicine 18: 157-170, 2017.

42. Hu M, Zhang Y, Guo X, Jia W, Liu G, Zhang J, Li J, Cui P, Sferruzzi-Perri AN, Han Y, et al: Hyperandrogenism and insulin resistance induce gravid uterine defects in association with mitochondrial dysfunction and aberrant reactive oxygen species production. Am J Physiol Endocrinol Metab 316: E794-E809, 2019.

43. Li X, Pishdari B, Cui P, Hu M, Yang HP, Guo YR, Jiang HY, Feng Y, Billig H and Shao R: Regulation of androgen receptor expression alters AMPK phosphorylation in the endometrium: In vivo and in vitro studies in women with polycystic ovary syndrome. Int J Bio Sci 11: 1376-1389, 2015.

44. Quaynor SD, Stradtman EW Jr, Kim HG, Shen Y, Chorich LP, Schreihofer DA and Layman LC: Delayed puberty and estrogen resistance in a woman with estrogen receptor alpha variant. N Engl J Med 369: 164-171, 2013.

45. Hamilton KJ, Arao Y and Korach KS: Estrogen hormone physiology: Reproductive findings from estrogen receptor mutant mice. Reprod Biol 14: 3-8, 2014.

46. Kim JJ, Choi YM, Choung SH, Yoon SH, Lee GH and Moon SY: Estrogen receptor beta gene $+1730 \mathrm{G} / \mathrm{A}$ polymorphism in women with polycystic ovary syndrome. Fertil Steril 93: 1942-1947, 2010.

47. Frolova AI and Moley KH: Glucose transporters in the uterus: An analysis of tissue distribution and proposed physiological roles. Reproduction 142: 211-220, 2011.

48. Frolova AI and Moley KH: Quantitative analysis of glucose transporter mRNAs in endometrial stromal cells reveals critical role of GLUT1 in uterine receptivity. Endocrinology 152: 2123-2128, 2011.

49. Frolova A, Flessner L, Chi M, Kim ST, Foyouzi-Yousefi N and Moley KH: Facilitative glucose transporter type 1 is differentially regulated by progesterone and estrogen in murine and human endometrial stromal cells. Endocrinology 150: 1512-1520, 2009.

50. Cui P, Li X, Wang X, Feng Y, Lin JF, Billig H and Shao R: Lack of cyclical fluctuations of endometrial GLUT4 expression in women with polycystic ovary syndrome: Evidence for direct regulation of GLUT4 by steroid hormones. BBA Clin 4: 85-91, 2015.

51. Li X, Cui P, Jiang HY, Guo YR, Pishdari B, Hu M, Feng Y, Billig $\mathrm{H}$ and Shao R: Reversing the reduced level of endometrial GLUT4 expression in polycystic ovary syndrome: A mechanistic study of metformin action. Am J Transl Res 7: 574-586, 2015.

52. Orostica L, Astorga I, Plaza-Parrochia F, Vera C, Garcia V, Carvajal R, Gabler F, Romero C and Vega M: Proinflammatory environment and role of TNF- $\alpha$ in endometrial function of obese women having polycystic ovarian syndrome. Int J Obes (Lond) 40: 1715-1722, 2016. 
53. Kim JY, Song H, Kim H, Kang HJ, Jun JH, Hong SR, Koong MK and Kim IS: Transcriptional profiling with a pathway-oriented analysis identifies dysregulated molecular phenotypes in the endometrium of patients with polycystic ovary syndrome. J Clin Endocrinol Metab 94: 1416-1426, 2009.

54. Evans J, Salamonsen LA, Winship A, Menkhorst E, Nie G, Gargett CE and Dimitriadis E: Fertile ground: Human endometrial programming and lessons in health and disease. Nat Rev Endocrinol 12: 654-667, 2016.

55. Hardiman P, Pillay OC and Atiomo W: Polycystic ovary syndrome and endometrial carcinoma. Lancet 361: 1810-1812, 2003.

56. Wang T, Zhang J, Hu M, Zhang Y, Cui P, Li X, Li J, Vestin E, Brännström M, Shao LR and Billig H: Differential expression patterns of glycolytic enzymes and mitochondria-dependent apoptosis in PCOS patients with endometrial hyperplasia, an early hallmark of endometrial cancer, in vivo and the impact of metformin in vitro. Int J Biol Sci 15: 714-725, 2019.

57. Couse JF, Curtis SW, Washburn TF, Lindzey J, Golding TS, Lubahn DB, Smithies O and Korach KS: Analysis of transcription and estrogen insensitivity in the female mouse after targeted disruption of the estrogen receptor gene. Mol Endocrinol 9: 1441-1454, 1995.

58. Schoneberg T, Kloos M, Brüser A, Kirchberger J and Sträter N: Structure and allosteric regulation of eukaryotic 6-phosphofructokinases. Biol Chem 394: 977-993, 2013.

59. Eto K, Sakura H, Yasuda K, Hayakawa T, Kawasaki E, Moriuchi R, Nagataki S, Yazaki Y and Kadowaki T: Cloning of a complete protein-coding sequence of human platelet-type phosphofructokinase isozyme from pancreatic islet. Biochem Biophys Res Commun 198: 990-998, 1994.
60. Hannemann A, Jandrig B, Gaunitz F, Eschrich K and Bigl M: Characterization of the human P-type 6-phosphofructo-1-kinase gene promoter in neural cell lines. Gene 345: 237-247, 2005.

61. Al Hasawi N, Alkandari MF and Luqmani YA: Phosphofructokinase: A mediator of glycolytic flux in cancer progression. Crit Rev Oncol Hematol 92: 312-321, 2014.

62. Hulchiy M, Nybacka A, Sahlin L and Hirschberg AL: Endometrial expression of estrogen receptors and the androgen receptor in women with polycystic ovary syndrome: A lifestyle intervention study. J Clin Endocrinol Metab 101: 561-571, 2016.

63. Shang K, Jia X, Qiao J, Kang J and Guan Y: Endometrial abnormality in women with polycystic ovary syndrome. Reprod Sci 19: 674-683, 2012.

64. Hu M, Li J, Zhang Y, Li X, Brännström M, Shao LR and Billig H: Endometrial progesterone receptor isoforms in women with polycystic ovary syndrome. Am J Transl Res 10: 2696-2705, 2018.

This work is licensed under a Creative Commons Attribution-NonCommercial-NoDerivatives 4.0 International (CC BY-NC-ND 4.0) License. 